\title{
MODERN BUSINESS MANAGEMENT MECHANISM WITH HYBRID STRUCTURE
}

\section{СУЧАСНИЙ МЕХАНІЗМ УПРАВЛІННЯ БІЗНЕСОМ З ГІБРИДНОЮ СТРУКТУРОЮ}

\author{
Valentyna Fostolovych ${ }^{1}$
}

DOI: https://doi.org/10.30525/978-9934-588-53-2-13

Abstract. The study examines the current state of economic development in Ukraine. It is noted that in order to develop the state it is necessary to find new ways focused on functioning in a digital society. It was found that it is important to shape the development strategy in such a way as to form strong ties and cooperation between government agencies, business structures and society. It is investigated that the social orientation of business is an important tool in the context of decentralization. An integrated environmental management system is an important condition for international cooperation. In today's world, the search for modern tools for the formation of a flexible management system is essential both at the level of business structures and at the level of management of regional associations.

The study is based on the construction of an innovation-oriented structure of business organization. The search for control systems with integrated modern tools adapted for use in the context of active digitalization is the main goal of scientific work. The subject of scientific research is the development of a business model with hybrid connections of its structural elements within one system. The use of innovative tools in the business structure management system will provide easy management of a complex mechanism. Execution of functional tasks within the newly formed business structure is focused on maximizing the economic and social effect and ensuring environmental safety.

The research methodology is based on the use of basic general scientific methods: analysis, synthesis, induction and deduction. Specific research

\footnotetext{
${ }^{1} \mathrm{Dr}$. PhD, Associate Professor of the Department of Accounting and Taxation in the Branches of the Economy,

Vinnytsia National Agrarian University, Ukraine
} 
methods were also used to build a business model of hybrid relationships between participants.

The model of modern business structure developed by us has territorial character. Territorial integration into a single production cycle of various participants in a business project will reduce the cost of production and enable the use of modern tools of the digital economy. Due to the use of the territorial principle of business organization, households, small, medium and large businesses will be involved in a single cycle. We have proposed a multi-level model of business organization based on linear relationships between system participants. The formation of a hybrid territorial business structure is an inevitable challenge of our time. All its participants, territorial communities, and the state will receive the maximum economic effect from the functioning of this structure.

At the state level, favorable conditions for small and medium-sized businesses should be provide, and an appropriate legal framework should be formed. The legal framework should facilitate the involvement of households in the general system of organization and conduct of business by medium and large enterprises. The formation of a territorial business association requires maximum simplicity and accessibility of legal registration of such business relations.

We investigated that the involvement of households and small enterprises in the system of functioning and implementation of business mechanisms organized at the regional level in the form of clusters will contribute to: reducing unemployment; reducing the size of social expenditures for the poor; increasing the amount of revenues to the budgets of different levels in the form of income taxes and more.

Due to the territorial location of the participants of such a joint hybrid business structure, modern tools become effective: the organization of transport logistics; use of the sharing economy with a functioning sharing platform at all levels of the business structure; extensive use of tender platforms; application of a single information management system of the territorial association with differentiated functions of access to information resources of the program; formation of integrated ordering platforms; use of artificial intelligence in the development of algorithms for management decisions and more. Due to the use of modern tools in general, the process of production of goods (works, services) becomes cheaper and makes them more competitive in the market. 
The developed model provides for business project participants of the services of professional companies in the following areas: financial services; business support; local business project management. The use of services of professional companies in the field of management and doing business will ensure the receipt of high quality services that contribute to maximum economic results. The functioning of such service companies in the structure of the territorial business association is a necessary part of the implementation of the strategic plan of the project as a whole, and the achievement of the goal of each of its participants. The use of outsourcing services will help to incur minimal costs for the maintenance of management staff. It is necessary to function in the structure of the territorial association of the logistics center. Using the services of the logistics center will avoid marketing costs and help sell products (goods, works, services) at the best prices.

The basis of the organization of the bio-cluster should be a closed production cycle. This approach will contribute to a significant increase in value added at each stage from the production of raw materials to its processing and sale of the finished product (goods, works, and services) to the final consumer.

Involvement in each of the stages of production and the management system of educational, research and scientific institutions will help to adapt the innovative direction of development and implementation of the principle of continuous improvement by all participants of the territorial business structure.

The model of organization of modern business structure developed by us will provide realization of the main strategy of the state and reception of the maximum effects by all its participants.

\section{1. Ветуп}

Сучасний стан економічного розвитку в Україні вимагає пошуку нових шляхів та інструментів для формування еластичної системи управління як на рівні бізнесових структур, так і на рівні управління регіональними об'єднаннями.

В основі дослідження лежить побудова інноваційно спрямованої структури організації бізнесу та сучасних інструментів управління ним. Пошук систем управління із інтегрованими сучасними інструментами адаптованими до застосування в умовах активної цифрові- 
зації є головною метою наукової праці. Предметом наукового дослідження виступає розробка бізнес-моделі із гібридними зв'язками іiі структурних елементів у межах однієї системи. Використання інноваційних інструментів в системі управління бізнесовою структурою забезпечить легке керування складним механізмом. Виконання функціональних завдань в межах новоутвореної бізнесової структури орієнтовано на максимальне отримання економічного та соціального ефекту і забезпечення екологічної безпеки.

В основі методології дослідження лежить використання основних загальнонаукових методів: аналізу, синтезу, індукції та дедукції. Також використано специфічні методи дослідження для побудови бізнес-моделі ка має гібридні зв'язки між учасниками.

Кожна система управління повинна бути орієнтована не лише на отримання максимальної величини економічної вигоди, але і бути орієнтованою на забезпечення соціального ефекту. Тому, головним завданням дослідження $\epsilon$ розробити сучасну модель організації бізнесу, яка передбачатиме інноваційний підхід до структури внутрішніх та зовнішніх зав'язків, застосування цифрових технологій у системі управління бізнесом та використання найбільш ефективних інструментів для реалізації бізнесової ідеї. Крім того, слід зважати на те, що вимогою сучасності $є$ така бізнесова структура, яка здатна реалізувати не лише економічну ціль проекту, але і поєднати іiі із соціальними інтересами територіальних громад та екологічною безпекою. Функціонуючи відособлено малі та мікро-підприємства неспроможні виконати такі вимоги через дефіцит фінансових ресурсів, знань та технічних і технологічних засобів. Лише користуючись вмінням та досвідом професійних структур організація навіть локального малого бізнесу сприятиме отриманню позитивних ефектів. Тому, необхідно побудувати таку модель бізнесу, яка буде передбачати ділові зв'язки між різними учасниками бізнес-проекту: домогосподарствами, мікропідприємствами, малими та великими підприємствами. Доцільно, щоб такі учасники функціонували у формі біо-кластера. До структури територіального об'єднання повинні входити обслуговуючі структури фінансового центру та центру управління бізнесом. Використання послуг аутсорсингу сприятиме мінімізації витрат за високоякісне обслуговування. Управління такою структурою є найважливішим завданням на 
шляху отримання запланованого результату. Реалізувати ефективну систему управління територіальним бізнесовим об'єднанням можливо при застосуванні автоматизованої системи управління із обмеженим доступом користувачів інформації до загальної інформаційної бази даних проекту.

\section{2. Дослідження економічного стану в Україні}

Оцінюючи стан доходів на одну особу в Україні варто відмітити іiі мізерні величини. Так, якщо у 2019 році місячний дохід на одну особу становив всього лише 5627,33 грн, що складає по курсу Євро станом на 31.12.2019 p. (26,422 грн/Свро) лише 212,98 Євро, тоді як у Німеччині за аналогічний період ця величина становить 3997,00 Євро. Що свідчить про потребу як на рівні держави, так і на рівні місцевих органів управління та підприємств вишукувати резерви для поліпшення стану доходів населення.

Ми вважаємо, що необхідно сформувати таку систему управління, яка б дала можливість залучати населення у систему організації бізнесу, що з однієї сторони сприятиме розвитку безпосередньо бізнесових структур за рахунок розширення об'ємів виробництва та реалізації товарів, робіт та послуг, а з іншої - збільшить можливість отримання додаткових надходжень у загальний підсумок доходів населення у формі додаткової заробітної плати та інших доходів фізичних осіб.

Нами проведено аналіз величини доходів і витрат населення в динаміці за роками (2010-2019 рр.). Результати оцінки представлено у таблиці 1.

Аналізуючи стан доходів населення України, отриманих впродовж 2019 р. виявлено, що вони становили 3699,3 млрд.грн./рік, тоді як величина їх витрат сягнула 3815,5 млрд.грн/рік. Тобто, населення не в стані накопичувати доходи та їх заощаджувати, а навіть вимушене у 2019 році зменшувати величину заощаджень на 116,2 млрд. грн. Тобто, сума наявного доходу у розрахунку на одну особу в розмірі 67528 грн. не $є$ достатньою, аби забезпечити елементарні потреби населення.

Така ситуація спонукає до пошуку нової ідеології та механізму організації бізнесу. Виникла потреба формувати бізнесову діяльність таким чином, щоб максимально залучити та поєднати потреби і інтереси таких учасників ринку як: 
Таблиця 1

Динаміка величини доходів і витрат населення впродовж 2010-2019 pp.

\begin{tabular}{|c|c|c|c|c|c|}
\hline Роки & Країна & $\begin{array}{c}\text { Доходи } \\
\text { населення }\end{array}$ & $\begin{array}{l}\text { Витрати } \\
\text { населення }\end{array}$ & \begin{tabular}{|c|} 
Наявний \\
річний \\
дохід \\
на одну \\
особу, нац. \\
валюта
\end{tabular} & \begin{tabular}{|c} 
Наявний \\
місячний \\
дохід \\
на одну \\
особу, нац. \\
валюта
\end{tabular} \\
\hline 2010 & Україна, грн/рік & 1101015 & 1101015 & 18346,8 & 1528,90 \\
\hline 2011 & & 1251005 & 1251005 & 21249,6 & 1770,80 \\
\hline 2012 & & 1407197 & 1407197 & 23931,6 & 1994,30 \\
\hline 2013 & & 1478073 & 1364755 & 26899,60 & 2241,63 \\
\hline 2014 & & 1516768 & 1485988 & 26782,1 & 2231,84 \\
\hline 2015 & & 1772016 & 1740943 & 31803,1 & 2650,26 \\
\hline 2016 & & 2051331 & 2038740 & 37079,9 & 3089,99 \\
\hline 2017 & & 2652082 & 2621444 & 47269,7 & 3939,14 \\
\hline 2018 & & 324873 & 3217183 & 58442 & 4870,17 \\
\hline \multirow[t]{5}{*}{2019} & & 3699346 & 3699346 & 67528 & 5627,33 \\
\hline & \multicolumn{5}{|c|}{ Порівняльні показники за країнами** } \\
\hline & Польща, PLN/мiс & & & & 5197,86 \\
\hline & Німеччина, EUR/міс & & & & 3997,00 \\
\hline & США, USD/год & & & & 23,87 \\
\hline
\end{tabular}

Джерело: узагальнено автором на основі * [3], ** [5]

- бізнесових структур;

- держави;

- населення.

На що і орієнтована розроблена нами модель організації бізнесу із міцними вертикально-інтегрованими зв'язками в межах тріади учасників ринку (бізнесові структури, держава, населення) основана на принципах:

- екологічної свідомості;

- соціальної відповідальності;

- економічної доцільності.

Оцінюючи стан і структуру доходів населення України у 2019 році нами виявлено, що у структурі доходів населення переважають надходження у формі заробітної плати (47,4\% від загальної величини отри- 
маних доходів) та 31,7\% доходів населення отримує у формі соціальних допомог та інших одержаних поточних трансфертів (табл. 2).

Лише 18,3\% отриманих доходів населення припадає на прибуток та змішаний дохід. Окрім того, населення України витрачає 92,1\% своїх доходів на погашення потреб у послугах та на придбання товарів що становить (3406202 грн). Усе це свідчить про досить низький рівень соціальної забезпеченості населення України.

Така ситуація викликає низький рівень соціальної активності населення та низький рівень їх мобільності. Проведена нами така оцінка стану і структури доходів населення підтверджує потребу у розробці нового механізму організації бізнесу та системи управління діяльністю підприємств як на державному рівні, так і на рівні бізнесових структур.

Із результатів проведеного дослідження виявлено нагальну потребу у розробці такої інтегрованої соціально орієнтованої екологічно направленої моделі організації бізнесу, яка передбачатиме створення нових робочих місць із залучення трудових ресурсів як на постійній основі, так і за договорами цивільно-правового характеру для виконання основних та разових робіт. Формування сучасних кластерів інтегрованих у систему організації регіонального бізнесу із залученням до їх структури роботи як великих підприємств, так і малих і мікро-підприємств та домогосподарств працюючих в єдиному інформаційному полі та програмному забезпеченні для формування логістики запитів, транспортної логістики та фінансового, управлінського, програмного і сервісного обслуговування.

Формування бізнесу із ідеологією яка відповідає світовим тенденціям із застосуванням сучасних можливостей цифровізації та штучного інтелекту спрямовано на вирішення екологічних проблем та соціальних потреб із отриманням достатньої економічної вигоди для мешканців територіальних громад, на території яких реалізовуватиметься бізнес-ідея.

Такий підхід вкрай є необхідним для подолання проблеми безробіття в Україні. Станом на 2019 рік в Україні мешкає 41,9 млн. населення, серед яких зареєстровано 17,4 млн. економічно активного населення, 15,9 млн. зайнятого та 1,5 млн. безробітного населення. Тобто, у 2019 році рівень безробіття в Україні сягнув 8,6\% (табл. 3). Звісно, це 
Таблиця 2

Стан та структура доходів і витрат населення України у 2019 році

\begin{tabular}{|c|c|c|c|}
\hline $\begin{array}{c}\text { Статті доходів і витрат населення } \\
\text { України }\end{array}$ & \begin{tabular}{|c|} 
Абсолютне \\
значення, \\
грн.
\end{tabular} & \begin{tabular}{|c|} 
Відносне \\
значення, \\
$\%$
\end{tabular} & $\begin{array}{c}\text { Відхилення, } \\
\text { у \% } \\
\text { до } 2018 \text { р. }\end{array}$ \\
\hline Доходи - всього & 3699346 & 100 & 113,9 \\
\hline Заробітна плата & 1753337 & 47,4 & 114,6 \\
\hline Прибуток та змішаний дохід & 678275 & 18,3 & 118,6 \\
\hline Доходи від власності (одержані) & 94481 & 2,6 & 103,6 \\
\hline $\begin{array}{l}\text { Соціальні допомоги та інші одержані } \\
\text { поточні трансферти }\end{array}$ & 1173253 & 31,7 & 111,1 \\
\hline у тому числі & & 0,0 & \\
\hline соціальні допомоги & 559308 & 15,1 & 120,1 \\
\hline інші поточні трансферти & 161964 & 4,4 & 112,3 \\
\hline соціальні трансферти в натурі & 451981 & 12,2 & 101,3 \\
\hline Витрати та заощадження - всього & 3699346 & 100,0 & 113,9 \\
\hline Придбання товарів та послуг & 3406202 & 92,1 & 118,1 \\
\hline Доходи від власності (сплачені) & 39273 & 1,1 & 131,0 \\
\hline $\begin{array}{l}\text { Поточні податки на доходи, майно та } \\
\text { iнші сплачені поточні трансферти }\end{array}$ & 370036 & 10,0 & 122,4 \\
\hline у тому числі & & 0,0 & \\
\hline поточні податки на доходи, майно тощо & 295767 & 8,0 & 119,0 \\
\hline внески на соціальне страхування & 3842 & 0,1 & 131,8 \\
\hline інші поточні трансферти & 70427 & 1,9 & 138,6 \\
\hline Нагромадження нефінансових активів & -21148 & $-0,6$ & $\mathrm{x}$ \\
\hline Приріст фінансових активів & -95017 & $-2,6$ & $\mathrm{x}$ \\
\hline 3 них & & 0,0 & \\
\hline $\begin{array}{l}\text { приріст грошових вкладів } \\
\text { та заощаджень у цінних паперах }\end{array}$ & 67452 & 1,8 & $\mathrm{x}$ \\
\hline заощадження в іноземній валюті & 53166 & 1,4 & $\mathrm{x}$ \\
\hline $\begin{array}{l}\text { позики, одержані за виключенням } \\
\text { погашених (-) }\end{array}$ & 24335 & 0,7 & $\mathrm{x}$ \\
\hline Наявний дохід & 2838056 & 76,7 & 114,9 \\
\hline Заощадження (приріст) & -116165 & $-3,1$ & 115,5 \\
\hline Наявний дохід на одну особу, грн & 67528 & $\mathrm{x}$ & 106,5 \\
\hline
\end{tabular}

Джерело: узагальнено автором на основі [3] 
нижчий показник ніж був у 2000 році, коли його величина становила $12,4 \%$, проте, вирішення такої проблеми потребує розробки плану та організації роботи територіальних громад таким чином, щоб звести його величину до мінімуму. Оцінку динаміки рівня безробіття в Україні проведено Міністерством фінансів та поставлено стратегічну ціль зменшити його величину.

В цілому, стратегією розвитку держави є поліпшення ï економічних показників та розвиток. Оцінюючи стан ВВП в Україні нами відмічено постійне зростання як номінального, так і реального його значення. Оцінюючи макроекономічний показник величину валового внутрішнього продукту (англ. Gross Domestic Product, GDP) ми бачимо загальну ринкову вартість усіх наявних кінцевих товарів і послуг, які вироблені за рік на території нашої держави у всіх галузях економіки та призначені як для споживання, експорту, так і для накопичення, незважаючи на національну приналежність використаних факторів виробництва.

Оцінюючи цей показник в динаміці за роками відмічено його зростання з 2012 року (30912,5 грн / душу населення) по 2019 рр. (94589,8 грн / душу населення) що майже втричі більше ніж у базовому періоді. Зважаючи на цінову політику та ситуацію на ринку ми можемо констатувати факт постійного зростання цін, що ускладнює проведення аналізу стану ВВП. Тому, розрізняють:

- номінальний ВВП;

- реальний ВВП.

Номінальний (абсолютний ВВП) на практиці розраховується у поточних (або у фактичних) цінах конкретного року. Тоді як реальний ВВП (розраховується із поправкою на інфляцію) визначається у цінах попереднього (чи іншого базового) року. В результаті, під час проведення аналізу стану ВВП у реальному ВВП враховується, в якій саме мірі зростання ВВП являється реальним фактом зростання виробництва, а не просто фактом зростанням цін на товари, роботи чи послуги.

В процесі проведення такої оцінки стану ВВП України та аналізуючи його реальну величину та номінальне значення, нами виявлено, що відхилення реального до номінального значення із роками коливається на 3,05 (у 2013 році) до 27,74\% (у 2015 році). У 2019 році його величина становила 7,52\%, що є позитивним напрямком (табл. 4). 
Таблиця 3 Оцінка динаміки рівня безробіття в Україні, 2000-2019 рр. (тис. осіб)

\begin{tabular}{|c|c|c|c|c|c|c|}
\hline Роки & 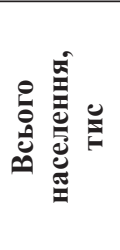 & 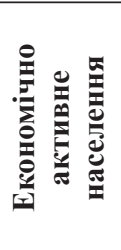 & 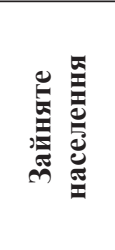 & 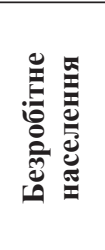 & 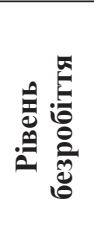 & 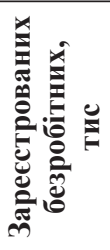 \\
\hline 2000 & 48923,2 & 21150,7 & 18520,7 & 2630,0 & $12,4 \%$ & 1178,7 \\
\hline 2001 & 48457,1 & 20893,6 & 18453,3 & 2440,3 & $11,7 \%$ & 1063,2 \\
\hline 2002 & 48003,5 & 20669,5 & 18540,9 & 2128,6 & $10,3 \%$ & 1028,1 \\
\hline 2003 & 47622,4 & 20618,1 & 18624,1 & 1994,0 & $9,7 \%$ & 1024,2 \\
\hline 2004 & 47280,8 & 20582,5 & 18694,3 & 1888,2 & $9,2 \%$ & 975,5 \\
\hline 2005 & 46929,5 & 20481,7 & 18886,5 & 1595,2 & $7,8 \%$ & 891,9 \\
\hline 2006 & 46646,0 & 20545,9 & 19032,2 & 1513,7 & $7,4 \%$ & 784,5 \\
\hline 2007 & 46372,7 & 20606,2 & 19189,5 & 1416,7 & $6,9 \%$ & 673,1 \\
\hline 2008 & 46143,7 & 20675,7 & 19251,7 & 1424,0 & $6,9 \%$ & 596,0 \\
\hline 2009 & 45962,9 & 20321,6 & 18365,0 & 1956,6 & $9,6 \%$ & 693,1 \\
\hline 2010 & 45778,5 & 20220,7 & 18436,5 & 1784,2 & $8,8 \%$ & 452,1 \\
\hline 2011 & 45633,6 & 20247,9 & 18516,2 & 1731,7 & $8,6 \%$ & 505,3 \\
\hline 2012 & 45553,0 & 20393,5 & 18736,9 & 1656,6 & $8,1 \%$ & 467,7 \\
\hline 2013 & 45426,2 & 20478,2 & 18901,8 & 1576,4 & $7,7 \%$ & 487,6 \\
\hline 2014 & 42928,9 & 19035,2 & 17188,1 & 1847,1 & $9,7 \%$ & 458,6 \\
\hline 2015 & 42760,5 & 17396,0 & 15742,0 & 1654,0 & $9,5 \%$ & 461,1 \\
\hline 2016 & 42584,5 & 17303,6 & 15626,1 & 1677,5 & $9,7 \%$ & 407,2 \\
\hline 2017 & 42386,4 & 17193,2 & 15495,9 & 1697,3 & $9,9 \%$ & 352,5 \\
\hline 2018 & 42153,2 & 17296,2 & 15718,6 & 1577,6 & $9,1 \%$ & 341,7 \\
\hline 2019 & 41902,4 & 17381,8 & 15894,9 & 1486,9 & $8,6 \%$ & 338,2 \\
\hline
\end{tabular}

Джерело: узагальнено автором на основі [3]

Збільшення розміру ВВП та зниження величини відхилення між реальним та номінальним його значенням характеризує реальний факт збільшення об'ємів виробництва, а не свідчить про зростання вартості товарів чи послуг, породжуваних зростанням рівня інфляції.

На практиці виділяють три методи, які використовують під час оцінки величини ВВП країни, а саме:

- виробничий метод (враховуючи величину доданої вартості); 
Таблиця 4

Динаміка ВВП України, 2012-2019 рр.

\begin{tabular}{|c|c|c|c|c|}
\hline Роки & $\begin{array}{c}\text { Номінальний } \\
\text { ВВП (в } \\
\text { фактичних } \\
\text { цінах) }\end{array}$ & $\begin{array}{c}\text { Реальний } \\
\text { ВВП (в цінах } \\
\text { попереднього } \\
\text { року) }\end{array}$ & $\begin{array}{c}\text { Відхилення } \\
\text { реального до } \\
\text { номінального } \\
\text { ВВП. \% }\end{array}$ & $\begin{array}{c}\text { ВВП на душу } \\
\text { населення, грн }\end{array}$ \\
\hline 2012 & 1408889 & 1304064 & $-7,44$ & 30912,5 \\
\hline 2013 & 1454931 & 1410609 & $-3,05$ & 31988,7 \\
\hline 2014 & 1566728 & 1365123 & $-12,87$ & 35834,0 \\
\hline 2015 & 1979458 & 1430290 & $-27,74$ & 46210,2 \\
\hline 2016 & 2383182 & 2034430 & $-14,63$ & 55853,5 \\
\hline 2017 & 2982920 & 2445587 & $-18,01$ & 70224,3 \\
\hline 2018 & 3558706 & 3083409 & $-13,36$ & 84192,0 \\
\hline 2019 & 3974564 & 3675728 & $-7,52$ & 94589,8 \\
\hline
\end{tabular}

Джерело: узагальнено автором на основі [1]

- розподільчий, чи дохідний метод (за розподілом величини доходів);

- витратний метод (за кінцевим використанням).

Зрозуміло, що кожен із методів повинен забезпечувати отримання подібних результатів. Аналізуючи динаміку стану та структури ВВП України за кінцевим використанням нами досліджено, що за роками, поряд із зростанням безпосередньо величини ВВП виявлено зростання величини і споживчих витрат.

Так, якщо у 2005 році величина споживчих витрат становила 76,5\% ВВП, то у 2019 році - цей показник зріс до 95,2\% ВВП, тоді як валове нагромадження знизилось у 2019 році до мінімальної позначки (12,6 \% ВВП) за останні аналізовані 15 років (табл. 5). При чому, експорт товарів та послуг по відношенню до величини ВВП також знижувався, $\mathrm{i}$ у 2019 році склав 41,2\% ВВП, що на 10,3\% менше при порівнянні із аналогічним показником у 2005 році. Проте, загальна вартість експорту товарів, робіт та послуг у 2019 році склала 1636416 млн. грн, тоді як у 2005 році його величина становила лише 227252 млн грн, що у 7,2 рази менше ніж у звітному році. Аналогічна ситуація із дещо вищими показниками амплітуди відмічене і стосовно імпорту товарів, робіт та послуг.

Так, якщо у 2005 році величина імпорту становила 223555 млн. грн, то у 2019 році цей показник сягнув позначки 1947599 млн. грн., що у 8,7 раз більше при порівнянні із базовим роком. 


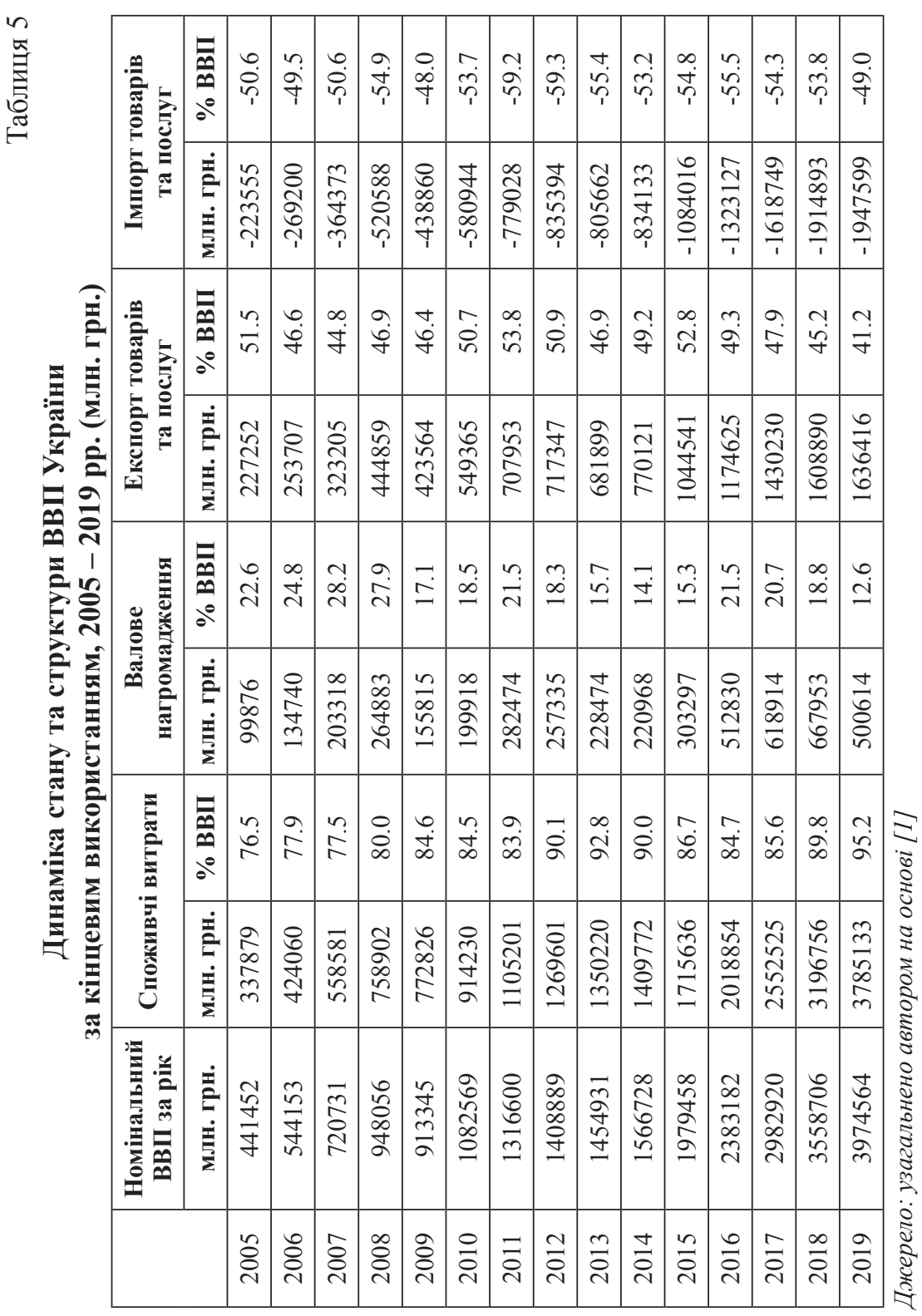


Очевидно, що поруч із збільшенням обсягів експортно-імпортних операцій, величина імпорту в Україну за даними оцінки у останні роки постійно випереджає об'єми експортних операцій, при цьому їх різниця часом досягає $8 \%$ величини ВВП.

Тому, ми бачимо, що потенціал в країни достатній, $є$ достатня кількість трудових ресурсів, виробляється маса товарів і послуг, які дають можливість забезпечити стрімкий розвиток країні за умови побудови ефективної системи управління із чітким виконанням принципів сучасних систем управління.

\section{3. Механізм управління бізнесом з гібридною структурою}

Україна $є$ унікальною державою із невичерпними ресурсами усіх видів, тому і потребує не стандартного та специфічного інтегрованого підходу до побудови системи управління, яка забезпечить ефективне їх використання та розподіл.

Викликає насторогу та розумінні у пошуку більш сучасного підходу до системи управління факт наявного державного боргу України та його динаміка.

Оцінюючи величину державного боргу враховано усі сукупні боргові зобов'язання держави наявні перед різними кредиторами (як юридичними, так і фізичними особами, іноземними державами, а також перед міжнародними організаціями, тощо). Державний борг України включає в себе заборгованість і центрального уряду, i регіональних й місцевих органів влади, й також борги всіх корпорацій із державною участю, пропорційно до частки держави у їхньому капіталі.

В цілому. державний борг України слід оцінювати із його позиції приналежності як зовнішній та внутрішній. Зовнішній державний борг виступає заборгованістю нашої держави іншим країнам та міжнародним економічним організаціям й іншим особам. Зовнішній державний борг виступає частиною валового зовнішнього боргу України. Величина зовнішнього державного боргу України на кінець 2019 року становила 839053,8 млн. грн., що у 8 раз більше при порівнянні із станом на аналогічний період 2009 року.

Внутрішній державний борг нашої держави включає в себе їі заборгованість перед власниками державних цінних паперів та іншими кре- 
диторами. У 2019 році його величина склала 1159221,6 млн. грн, тоді як у 2009 році це значення було у 5,5 раз меншим (221751,7 млн. грн).

Зрозуміло, що борг у держави виникає при здійсненні країною фінансових запозичень, та внаслідок укладання договорів та угод про надання кредитів й позик, та проведення пролонгації і реструктуризації боргових зобов'язань за попередні роки. Загальний борг нашої держави на кінець 2019 року становив 2255552,8 млн. грн., тоді як у 2009 році його значення було на рівні 316884,6 тис. грн. Сукупність усіх боргових зобов'язань нашої держави містить також у собі і гарантований державою борг, який виникає унаслідок прийнятих державою гарантій на себе за зобов'язаннями третіх осіб (чи прийнятих державою на себе зобов'язання третіх осіб).

Таблиця 6

Динаміка величини державного та гарантованого державою боргу України, 2009 - 2020 рр. (млн. грн.)

\begin{tabular}{|c|c|c|c|c|c|c|}
\hline \multirow[b]{2}{*}{ Період } & \multicolumn{2}{|c|}{ Загальний } & \multicolumn{2}{|c|}{ Внутрішній } & \multicolumn{2}{|c|}{ Зовнішній } \\
\hline & $\begin{array}{l}\dot{\bar{z}} \\
\dot{\vec{E}} \\
\dot{\vec{g}}\end{array}$ & 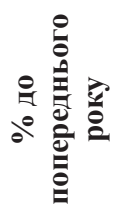 & $\begin{array}{l}\dot{\bar{\Xi}} \\
\dot{\vec{E}} \\
\dot{E}\end{array}$ & 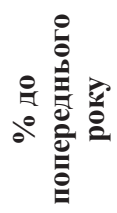 & $\begin{array}{l}\dot{\bar{\Xi}} \\
\dot{\vec{E}} \\
\dot{\vec{E}}\end{array}$ & 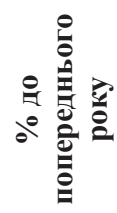 \\
\hline 31.12 .2009 & 316884,6 & & 211751,7 & & 105132,9 & \\
\hline 31.12 .2010 & 432235,4 & $36.4 \%$ & 276745,6 & $30.7 \%$ & 155489,8 & $47.9 \%$ \\
\hline 31.12 .2011 & 473121,6 & $9.5 \%$ & 299413,9 & $8.2 \%$ & 173707,7 & $11.7 \%$ \\
\hline 31.12 .2012 & 515510,6 & $9.0 \%$ & 308999,8 & $3.2 \%$ & 206510,7 & $18.9 \%$ \\
\hline 31.12 .2013 & 584114,1 & $13.3 \%$ & 300025,4 & $-2.9 \%$ & 284088,7 & $37.6 \%$ \\
\hline 31.12 .2014 & 1100564,0 & $88.4 \%$ & 611697,1 & $103.9 \%$ & 488866,9 & $72.1 \%$ \\
\hline 31.12 .2015 & 1572180,2 & $42.9 \%$ & 1042719,6 & $70.5 \%$ & 529460,6 & $8.3 \%$ \\
\hline 31.12 .2016 & 1929758,7 & $22.7 \%$ & 1240028,7 & $18.9 \%$ & 689730,0 & $30.3 \%$ \\
\hline 31.12 .2017 & 2141674,4 & $11.0 \%$ & 1374995,5 & $10.9 \%$ & 766678,9 & $11.2 \%$ \\
\hline 31.12 .2018 & 2168627,1 & $1.3 \%$ & 1397217,8 & $1.6 \%$ & 771409,3 & $0.6 \%$ \\
\hline 31.12 .2019 & 1998275,4 & $-7.9 \%$ & 1159221,6 & $-17.0 \%$ & 839053,8 & $8.8 \%$ \\
\hline 31.03 .2020 & 2255552,8 & $12.9 \%$ & 1387805,0 & $19.7 \%$ & 867747,7 & $3.4 \%$ \\
\hline
\end{tabular}

Джерело: узагальнено автором на основі [2] 
Тривожними є показники динаміки зростання державного боргу України у 2020 році. Якщо на 31.12.2019 року загальний борг становив 1998275,4 млн. грн., то на кінець 1 кварталу 2020 року він зріс до величини 2255552,8 млн. грн., що майже на $13 \%$ більше при порівнянні із даними початку цього року. При чому, величина зовнішнього боргу за визначений період (1 квартал 2020 року) зросла на 19,7\% (табл. 6).

Структуру державного і гарантованого державою боргу відповідно до даних даними Міністерства фінансів України в динаміці за роками та станом на 31.03.2020 нами представлено у таблиці 6.

Проведені нами дослідження стану економічного розвитку держави та рівня заборгованості держави свідчать про нагальну потребу впровадження сучасних підходів до системи управління як на рівні держави, так і на рівні підприємств. Сучасні ринкові умови, високий рівень конкуренції, вимоги до організації бізнесу орієнтованого на забезпечення екологічних параметрів, реалізацію соціальних потреб та стрімкий розвиток цифровізації вимагають формування нетрадиційних інтегрованих моделей організації бізнесу та побудови вертикально-інтегрованих систем управління ним.

Залученими у загальну схему бізнесу та виробничого процесу повинні бути усі рівні народного господарства: від домогосподарств, мікро- та малих підприємств, підприємств різних розмірів та організаційно-правових форм власності до великих корпорацій, наукових, дослідних та навчальних установ.

Великі об'єднання, корпорації та холдинги, володіючи потужною ресурсною базою та можливістю залучити у виробничий процес висококваліфікованих логістів, менеджерів та працівників інноваційної сфери уможливлять застосування сучасних автоматизованих технологій як системи управління, так і безпосередньо виробництва основаного на інтенсивному використанні автоматизованих процесів, цифрових технологій та штучного інтелекту. Тому, доцільним є створити такі регіональні бізнесові структури, які будуть функціонувати у єдиній логістичній системі та міцній співпраці в межах одного стратегічного плану із єдиною потужною системою менеджменту у загальній логістичній схемі із структурами різних рівнів:

1-й рівень - із науковими та дослідними центрами (центр інноваційного розвитку), 
2-й рівень - із центром підтримки бізнесу (фінансовим центром та центром управління бізнесом),

3-й рівень - торговим домом (структура, яка формуватиме внутрішню та міжнародну логістику реалізації товарів та послуг вироблених в межах регіональної бізнесової структури);

4-й рівень - відокремленими виробничими структурами (інтегровані кластери основані на співпраці малих, середніх і мікро- підприємств та домогосподарств у межах однієї логістичної системи).

За допомогою широкого застосування мікрокредитування домогосподарств та малих і мікропідприємств, залучених у бізнес проект як відокремлені самостійні структури із постійним супроводом реалізації частини ідеї через центр підтримки бізнесу вертикально-інтегрованої структури економічні переваги буде отримано усіма сторонами. Оскільки буде забезпечено:

- інноваційний підхід у реалізації ідеї;

- мінімізацію ризиків за рахунок постійного супроводу спеціалістами центру підтримки бізнесу;

- впровадження систему менеджменту в процесі здійснення виробничої діяльності, яка є не можливою та економічно недоцільною при одноосібному господарюванні;

- обслуговування системи обліку, оподаткування, документування операцій, юридичну підтримку через аутсорсингові послуги, які надаватиме центр підтримки бізнесу;

- інші додаткові послуги, включно із послугами маркетингу та збуту товарів, робіт і послуг, що забезпечить торговий дім.

Основними характеристиками такої структури виступають:

- розміщення за територіальним принципом та розподіл підприємств різних видів діяльності;

- використання інноваційного підходу до забезпечення виробничого процесу та організації системи управління як окремими елементами (учасниками), так і на рівні управління всією структурою завдяки роботі науково-дослідних та навчальних установ, як активних учасників бізнес-проекту в напрямку розробки та впровадження інновацій;

- об’єднання учасників бізнес-проекту в єдиний виробничий ланцюг для формування достатньої кількості партій продукції, товарів, робіт чи послуг; 
- чітка координація дій учасників структури через організацію єдиної автоматизованої системи управління сегментованої (оперативні та тактичні плани) для кожного учасника в межах реалізації стратегічної мети (бізнес-план);

- високоефективна система менеджменту та маркетингу, організована в межах єдиного логістичного ланцюга завдяки користуванню послугами висококваліфікованих спеціалістів центру підтримки бізнесу;

- якісна система правового забезпечення та системи обслуговування системи обліку через послуги аутсорсингової компанії, як учасника бізнес-проекту;

- посилення ефекту від використання сукупності факторів позитивного впливу орієнтованих на розвиток кожного із елементів бізнесової структури, що проявляється у формі синергетичного ефекту;

- використання сучасних інструментів ефективної системи організації бізнесу та системи управління ними;

- широке використання цифрових технологій, автоматизованих систем із можливістю роботи у режимі онлайн за допомогою віддаленого доступу та штучного інтелекту.

Проте, варто зазначити, що навіть ідеально організована схема та структура проекту не буде ефективною без досконалої системи управління. При управлінні багатоелементною структурою із різнонаправленими видами діяльності в межах єдиної стратегічної мети слід розробити та впровадити інтегровану автоматизовану систему управління. Потрібно наладити систему організації роботи кожного із елементів таким чином, щоб вони працювали доповнюючи своїми функціями усю система в межах визначеного сегмента.

Важливим елементом даної схеми $є$ центр інноваційного розвитку. До його структури повинні увійти науково-дослідні та навчальні структури, які будуть:

1. Здійснювати дослідження сучасних інноваційних екологічно безпечних технологій.

2. Проводити оцінку економічної та соціальної доцільності їх впровадження.

3. Адаптувати методику впровадження інноваційних розробок до конкретних умов господарювання кожного із учасників бізнеспроекту. 
4. Проводити навчання з метою підготовки якісного висококваліфікованого персоналу та забезпечувати умови підвищення кваліфікації працівників відповідно до зміни умов та техніки і технології виконання завдань.

Лише на основі глибокого вивчення та оцінки сучасних технологій та методів управління можливим $є$ отримання позитивного економічного результату. 3 метою якісного комплексного обслуговування учасників територіального бізнесового об'єднання повинен працювати центр підтримки бізнесу. У його складі функціонує:

1. Фінансовий центр - обслуговуючими установами якого є: банк, страхова компанія, лізингова компанія.

2. Центр управління бізнесом - обслуговуючими структурами якого є: департамент правового забезпечення, аутсорсингова компанія, департамент управління та внутрішньої логістики.

В межах територіальної бізнесової структури наявність фінансового центру є важливим елементом забезпечення успішного та комплексного обслуговування усіх його учасників та надання додаткових послуг іншим клієнтам.

Забезпечити повний цикл обслуговування як учасників бізнес проекту в особі: підприємств, фізичних осіб, корпорацій; так і покупців в особі юридичних, фізичних осіб, іноземних компаній та їх філій повинен комплекс із: установи банку, страхової компанії та лізингової компанії.

Крім виконання основних функцій банку лежить забезпечення спеціального режиму мікрокредитування учасників бізнес-проекту. Головною метою такого фінансового механізму є посилення рівня конкурентоспроможності мікро-, малих та середніх підприємств (ММСП) а також активних у господарській діяльності домогосподарств шляхом фінансування інвестицій через надання кредитів на реалізацію бізнес-ідеї, реалізовуваної в межах стратегічного плану проекту. Банк розглядатиме подані заявки на відповідність вимогам проекту. Експерти банків із кредитування проаналізують бізнес-ідею, проведуть оцінку обсягу потреби у кредитних коштах, дослідять можливості обслуговування очікуваного кредиту й умови забезпечення його повернення.

Лише після цього, працюючи із страховою компанією бізнес-проекту в межах єдиної операції буде оформлено мікро-кредит на умовах 
співпраці із лізинговою компанією та структурами центру управління бізнесом, що функціонують в межах одного проекту.

Доцільним є запровадження нового механізму в системі банківського обслуговування - створення краудфандингової платформи мікрокредитування («Person-to-Person» - англ. «від людини до людини»), так званої платформи фандрайзинг і краудфандинг (Fundraising and Crowdfunding). Найбільш поширеними такими платформами є: Kickstarter (URL: https://www.kickstarter.com/?ref=nav), GoFundMe (URL: https://www.gofundme.com/), IndieGoGo (URL: https://www.indiegogo.com/), FundLy (URL: https://fundly.com/) та інші.

Створена платформа сумісного інвестування стане новим викликом сучасності на шляху соціального зростання бізнес-ідей малого підприємництва. Впровадження в одній структурі банківського мікро-кредитування та платформ сумісного інвестування (фандрайзингу та краудфандигу) посилить конкурентну боротьбу за ринок надання послуг кліснтам, що сприятиме поліпшенню їх якісного та сервісного обслуговування. А система цифрової репутації клієнтів сприятиме збільшенню рівня відповідальності за зобов'язаннями перед кредиторами. Кожна життєздатна бізнес-ідея отримає висококваліфіковану підтримку та супровід впродовж усього терміну її реалізації за допомогою укладених договорів на обслуговування із:

- департаментом правового забезпечення (від вибору форми господарювання до оформлення документів на реєстрацію);

- аутсорсинговою компанією (від реєстрації суб'єкта господарювання та облікового забезпечення до формування фінансової звітності);

- департаментом управління та внутрішньої логістики, якими буде надаватись покрокова схема дій та методологія забезпечення виробничого процесу завдяки розробленим технологічним картам за кожним із процесів проекту. Система внутрішньої логістики забезпечить інтенсивне впровадження шарінг-економіки (sharing economy), чи економіки сумісного використання (Collaborative Consumption). Така сучасна економічна бізнес-модель передбачає на основі використання онлайн-платформи забезпечувати економічно вигідне використання активів (необоротних активів, товарів, робіт, послуг), які у виробничому процесі задіяні не постійно, та є недоцільними для придбання. При цьому, користувач оплачуватиме лише за тимчасовий доступ до продукту. 
Функціонуючий в межах аутсорсингової компанії департамент економічного розвитку та соціальної підтримки бізнесу забезпечить:

- опрацювання варіантів інноваційного розвитку та розробку алгоритмів адаптування пропозицій інноваційної діяльності кожного із учасників територіального бізнесового об'єднання;

- проведення аналізу впроваджених інноваційних складових, та оцінку пропозицій постійного поліпшення за кожним із проектів.

Використання послуг департамент економічного розвитку та соціальної підтримки бізнесу для його учасників сприятимуть:

- зведуть до мінімуму помилки та прорахунки у підходах до організації бізнесу на етапі проектної розробки;

- проведуть оцінку ефективності та доцільності впровадження елементів удосконалення, запропонованих за кожним із проектів;

- здійснюватимуть аналітичний супровід проектів та координуватимуть їх розвиток в інноваційній сфері.

В основі управління кожним із напрямків проекту повинен лежати цикл Демінга, базованого на принципі постійного поліпшення. Формуючи алгоритм дій для кожного із проектів абсолютно різних видів та напрямків діяльності необхідно:

1) сформувати інформаційну базу про проект та його характеристики, проаналізувати та узагальнити інформацію для розробки покрокового плану дій та алгоритму їх реалізації;

2) прийняти рішення про вибір найбільш оптимальних інструментів для отримання визначеного результату та забезпечити координацію процесами із розробкою прогнозних показників та результатів;

3) забезпечити контроль за покроковим виконанням завдань та реалізацією пунктів алгоритму;

4) провести аналіз та дати оцінку ефективності реалізованому завданню із розробкою наступних елементів удосконалення для поліпшення результатів.

Цикл таких етапів є безперервним, оскільки передбачає постійне удосконалення як виробничого процесу, так і інтегрування нових технологій і систем управління у проект.

Реалізувати такий механізм управління із використанням масиву даних і автоматизованої розробки алгоритмів дій самостійно учасниками проекту (суб'єктами мікрокредитування) дуже складно. Тому, 
найбільш ефективним для власників локальних бізнес-ідей, із мінімальними ризиками для кредитора (або інвестора такої ідеї) є користування ініціатором проекту висококваліфікованими послугами спеціалістів департаменту управління територіальної бізнесової структури. Існує безліч негативних світових практик, коли ідеально організовані структури ставали банкрутами через неефективну систему управління ними. Система управління будь-якого бізнесу не може бути стандартною уніфікованою схемою етапів, яка б підходила під будь-які форми і умови господарювання. Кожну модель управління потрібно адаптувати під умови функціонування та конкретну організаційно-праву форму господарюючого суб'єкта. Досягти успіху в управлінні великою територіальною бізнесовою структурою $є$ важливою задачею на шляху ефективного, екологічного безпечного та соціально зорієнтованого функціонування інноваційного новоутворення. Реалії сучасності вимагають від підприємства:

- постійного динамічного росту, збільшення економічної вигоди;

- застосування інноваційних технологій та розробок;

- високого рівня еластичності в усіх видах діяльності відповідно до зміни потреб споживачів та умов які ставить держава та інше.

Тому, важливою на сьогодні є не організаційно-правова форма власності під час створення бізнесу, а організація ефективної роботи в усіх складових (структурних елементах) бізнес-проекту. Така робота вимагає від управлінського персоналу достатньої кількості знань, вмінь та навиків. Також важливим елементом ефективного управління $\epsilon$ вміння системно мислити і приймати рішення на основі множинної інформації сформованої на основі банку даних усієї структури. Спроможність працювати із інформаційною базою даних та складними програмними продуктами обслуговуючими усі структурні частини територіального новоутворення $є$ складовими успіху бізнесу. Проте, такими навичками володіють не усі працівники адміністративного апарату та розробники бізнес-ідей. Отже, при створенні гібридної територіальної бізнесової структури необхідне функціонування не лише аутсорсингової компанії, але і департаменту управління та внутрішньої логістики.

Широке використання учасниками проекту послуг аутсорсингу та послуг які надає департамент менеджменту і внутрішньої логістики дасть можливість отримати заплановану кількість продукції (товарів, 
робіт чи послуг) відповідної якості із оптимальною величиною понесених витрат. Проте, для отримання бажаного економічного ефекту не достатнім $\epsilon$ лише виробити продукцію. Важливим елементом успіху $є$ етап реалізації виробленого продукту.

Нами запропоновано, щоб безпосередньо функції реалізації виробленої продукції (товарів, робіт та послуг) в межах учасників територіальної бізнесової структури здійснював логістичний центр.

Головними функціями сучасного логістичного центру є:

- формування партій товару в необхідних об'ємах для реалізації;

- підтримка цифрової платформи готової продукції (товарів, робіт, послуг);

- забезпечення транспортної логістики доставки товару на склади;

- пошук ринків збуту та реалізація сформованих партій продукції (товарів, робіт, послуг).

Виробництво продукції повинно здійснюватися в межах біокластера із замкнутим циклом виробництва [5]. 3 метою забезпечення розвитку територіальних громад вважаємо за доцільне роботу біокластера сформувати також не за традиційною моделлю, а за гідридною схемою. При цьому слід поєднати у одній схемі співпрацю об'єднаної аграрно-промислової структури із малими та мікро-підприємствами, а також долучивши у виробничий процес домогосподарства. Учасники біокластера матимуть можливість при організації бізнесу користуватись послугами установ центру підтримки бізнесу. На основі договорів між відповідною юридичною особою територіального бізнесового об'єднання та потенційним учасником бізнес проекту буде надаватись висококваліфікована підтримка працівниками департаменту правового забезпечення в процесі підготовки документації та супроводу під час реалізації бізнес-ідеї. Відповідним чином сформований локальний бізнес-проект буде оцінено установами фінансового центру. У випадку погодження локальної бізнес-ідеї, запропонованої користувачем (домогосподарство, мікро-підприємство, мале підприємство, науково-виробничий комплекс чи ін.) обслуговуючий територіальну бізнесову структуру банк ініціюватиме видачу мікро-кредиту. Страхова компанія після відповідної оцінки ризиків стане поручителем при видачі кредиту. Альтернативним варіантом отримання фінансування бізнес-ідеї $\epsilon$ паралельно організована платформа сумісного інвестування впрова- 
джена у одній структурі банківського мікро-кредитування (фандрайзинг та краудфандиг). Проте, використання альтернативного варіанту потребує високого цифрового рейтингу клієнта.

Організувати технічне забезпечення локальної бізнес-ідеї допоможе лізингова компанія, яка виступає структурною частиною фінансового центру територіального бізнесового об'єднання. Структури центру управління бізнесом стануть надійними партнерами та супровідними інстанціями до успішного бізнесу. Вони сформують головні орієнтири сучасних підходів до розвитку інноваційних технологій та сучасних систем управління для досягнення максимального економічного, екологічного та соціального ефекту.

Управляти розвитком такої інноваційної територіальної структури та її учасників повинні професіонали. Тому функції фінансового центру та центру управління бізнесом повинні виконувати відповідні установи, які володіють необхідними для цього ресурсами, технологіями та навичками. Таким чином організована система ведення бізнесу дасть можливість провадити заплановану на рівні стратегічного плану територіального бізнесового об'єднання інноваційну політику. Сформувавши такі гібридні територіальні бізнесові об'єднання, діяльність яких буде націлена на реалізацію стратегії розвитку держави, співпрацю державних та бізнесових структур, забезпечення соціального розвитку та екологічної безпеки - забезпечить стрімкий розвиток інноваційної економіки держави в цілому.

Використання на кожному етапі функціонування територіальної бізнесової структури інноваційного підходу при виконанні умов принципу постійного поліпшення шляхом співпраці науково-дослідних та навчальних установ із установами центру підтримки бізнесу, логістичного центру та біокластера забезпечить синергетичний ефект в отриманні економічного, екологічного та соціального ефекту. Таке поєднання та взаємодоповнення функцій наукової, технічної, промислової, економічної, екологічної та соціальної політики в єдиному технологічному процесі забезпечить унікальні сприятливі умови інтенсивного розвитку інновацій, які є основою економічного благополуччя. В даній структурі системі менеджменту слід призначити чільне місце. Оскільки саме від знань, практичного досвіду, вміння використовувати елементи сучасних технологій управління в системі програмного 
забезпечення у режимі онлайн із доступом «24x7», еластичності у прийнятті управлінських рішень залежно від ситуації та вибору альтернативного алгоритму запропонованої програмним продуктом залежить ефективність організації процесу та управління ситуацією. Кінцевий результат залежить від правильної організації процесу, технічних можливостей та простоти зав'язків між елементами у складній структурі.

Однозначним є те, що у такій об'єднаній гібридній структурі повинна широко використовуватись єдина автоматизована система із розподілом прав доступу до відповідних сегментів інформаційної бази даних на кожному із рівнів та єдиним доступом до обслуговуючих платформ. Ефективне управління таким проектом є можливим при:

- широкому використанні цифровізації на усіх рівнях;

- інтенсивному використанню обслуговуючих платформ;

- застосуванню штучного інтелекту та сучасних IT-ресурсів;

- наявності комплексного програмного забезпечення спроможного поєднати системи реєстрації фактів та системи управління.

Наявність комплексного програмного продукту та злагодженого управлінського персоналу - $є$ зв'язуючим елементом, який поєднає усі структурні складові територіального бізнесового об'єднання.

Програмний продукт повинен бути максимально налаштованим для використання усього масиву даних та адаптованим для використання в процесі прийняття науково обгрунтованого виваженого управлінського рішення. Автоматизована система управління повинна постійно використовуватись вищим керівництвом територіального об’єднання для прийняття рішень виключно на основі даних актуальної оперативної структурованої за запитом інформації, сформованої у єдиній інформаційній базі даних.

В цілому, економіка територіального бізнесового проекту є гібридною, оскільки потребує не бюрократичних процедур, а реального максимально простого способу вирішення проблеми чи виконання завдання в момент його постановки в режимі онлайн при віддаленому доступі. Для реалізації цього необхідною умовою $є$ наявність такого програмного продукту, який буде відповідати зазначеним вимогам, тобто, забезпечить швидкий та легкий доступ до ресурсів та можливість автоматизованого управління ними. В такій системі повинні узгоджено співпрацювати за допомогою безпровідного зв'язку тех- 
нічні пристрої та системи контролю із функціями штучного інтелекту. Система оперативного і тактичного планування повинна бути еластичною при зміні факторів впливу та орієнтованою виключно на вихідні параметри стратегічного плану. Програмний продукт повинен бути налаштованим таким чином, щоб поєднати у єдину систему стратегічний план із якого будуть виходити:

1. Конкурентні плани (ринкові тактичні плани) кожного із структурних частин територіального об'єднання (план центру підтримки бізнесу, логістичного центру, біокластера та центру соціального розвитку і відновлюваної медицини).

2. Функціональні плани, які будуть сформовані в межах установ головних структур (наприклад, бізнес-план центру підтримки бізнесу включатиме у себе тактичні плани: 1) фінансового центру установами якого є банк, страхова компанія та лізингова компанія; 2) центру управління бізнесом, якого структурами є департамент правового забезпечення, аутсорсингова компанія та департамент управління та внутрішньої логістики) та інше.

3. Портфельні, або оперативні плани, включатимуть плани функціональних підрозділів компанії (Наприклад, план аутсорсингової компанії міститиме у собі елементи планів ії відділів: департаменту обліку та оподаткування,Ю департаменту економічного розвитку та соціальної підтримки бізнесу, департаменту аудиту проектів, департаменту ІТ-технологій).

Кожен із етапів функціонування такої територіальної бізнесової структури передбачає реалізацію конкурентної стратегії відповідного рівня. Топовими задачами реалізації такої стратегії є постійне підвищення конкурентоспроможності усіх учасників проекту. Синергетичний ефект від виконання завдань кожного із учасників проявляється у тому, що реалізація заходів буде приносити економічний ефект виконавцю, а відповідно і усій структурі. Оподаткування отриманих доходів учасників забезпечить додаткові надходження як до місцевих, так i до державного бюджету України.

Позитивні моменти діяльності такого територіального бізнесового об'єднання проявляються у:

- посиленні факторів конкурентної боротьби кожного із учасників проекту; 
- створення бар'єрів для конкурентів та унеможливлення їх витіснити із зайнятого сегменту ринку за рахунок виробництва конкурентної екологічно безпечної продукції і соціальної направленості дій усіма учасниками проекту;

- зниження величини витрат на транзакції між учасниками проекту за рахунок обслуговування єдиними структурами фінансового центру та центру управління бізнесом;

- спрощення процедури виходу на міжнародний ринок із ціллю експорту виробленої усіма учасниками територіального об'єднання продукції (товарів, робіт, послуг) за допомогою послуг Центру зовнішньої логістики.

\section{4. Висновки}

Отже, формування гібридної територіальної бізнесової структури $\epsilon$ неминучим викликом сучасності. Від функціонування даної структури отримають максимальний економічний ефект усі його учасники та територіальні громади і держава.

На рівні держави слід забезпечити сприятливі умови для роботи малого та середнього бізнесу, та сформувати правову базу таким чином, щоб залучення домогосподарств до загальної системи організації та ведення бізнесу середніми та великими підприємствами було максимально доступним, простим та вигідним усім сторонам.

Ми вважаємо, що залучення домогосподарств та малих підприємств у систему функціонування та реалізації бізнесових механізмів організованих на регіональному рівні у формі кластерів сприятиме:

- зниженню рівня безробіття;

- зменшення величини соціальних видатків малозабезпеченим верствам населення;

- підвищенню сум надходжень у бюджети різних рівнів у формі податків із доходів.

Завдяки територіальному розміщенню учасників такої об'єднаної гібридної бізнесової структури ефективними стають інструменти транспортної логістики, шарінг-економіки, тендерних платформ, єдиної інформаційної системи управління, формування об'єднаних платформ замовлень та інше, що здешевлює в цілому процес виробництва товарів (робіт, послуг) та робить їх більш конкурентоспроможними на ринку. 
Використання послуг професійних компаній в сфері фінансового обслуговування та підтримки бізнесу кожним із учасників проекту забезпечить отримання високоякісних послуг із мінімальними витратами на утримання управлінського апарату.

Користування послугами логістичного центру дасть можливість уникнути витрат маркетингу та допоможе реалізувати вироблену продукцію (товари, роботи, послуги) за максимально вигідними цінами.

Формування замкнутого циклу виробництва в межах функціонування структурних елементів біокластера сприятиме значному зростанню доданої вартості на кожному із етапів від виробництва сировини, до іiі переробки та реалізації готового продукту кінцевому споживачу.

Залучення у кожен із етапів виробництва та систему управління навчально-дослідних та наукових установ сприятиме адаптуванню інноваційного напрямку розвитку та реалізації принципу постійного поліпшення усіма учасниками територіальної бізнесової структури.

\section{Список літератури:}

1. Державна служба статистики України. Валовий внутрішній продукт (ВВП) в Україні 2020. URL: https://index.minfin.com.ua/ua/economy/gdp/ (дата звернення: 10.05.2020).

2. Державна служба статистики України. Державний борг України. URL: https://index.minfin.com.ua/ua/finance/debtgov/ (дата звернення: 10.05.2020).

3. Державна служба статистики України (2020). Доходи та витрати населення України. URL: https://ukrstat.org/uk/operativ/operativ2007/gdn/dvn $\mathrm{ric} / \mathrm{dvn}$ ric_u/arh_dvn_kv_u.htm (дата звернення: 10.05.2020).

4. Державна служба статистики України. Рівень безробіття в Україні. URL: https://index.minfin.com.ua/ua/labour/unemploy/ (дата звернення: 10.05.2020).

5. Державна служба статистики України. Середня місячна заробітна плата у різних країнах. URL: https://index.minfin.com.ua/ua/labour/salary/world/ (дата звернення: 10.05.2020).

6. Фостолович В.А., Шинькович А.В. Сучасна вертикально-інтегрована модель організації бізнесу із замкнутим циклом виробництва. Економіка, фінанси. менеджмент: актуальні питання науки $i$ практики. 2019. № 8(48). C. $86-103$.

\section{References:}

1. Derzhavna sluzhba statystyky Ukrainy (2020). Valovyj vnutrishnij produkt (VVP) v Ukrajini 2020 [Gross domestic product (GDP) in Ukraine 2020]. Kyiv: Informatsiino-analitychne ahentstvo. Retrieved from: https://index.minfin.com.ua/ ua/economy/gdp/ (accessed 10 May 2020). 
2. Derzhavna sluzhba statystyky Ukrainy (2020). Derzhavnyj borgh Ukrajiny [Public debt of Ukraine]. Kyiv: Informatsiino-analitychne ahentstvo. Retrieved from: https://index.minfin.com.ua/ua/finance/debtgov/ (accessed 10 May 2020).

3. Derzhavna sluzhba statystyky Ukrainy (2020). Dokhody ta vytraty naselennja Ukrajiny [Incomes and expenditures of the population of Ukraine]. Kyiv: Informatsiino-analitychne ahentstvo. Retrieved from: https://ukrstat.org/uk/operativ/ operativ2007/gdn/dvn_ric/dvn_ric_u/arh_dvn_kv_u.htm (accessed 10 May 2020).

4. Derzhavna sluzhba statystyky Ukrainy $(2 \overline{0} 20)$. Rivenj bezrobittja v Ukrajini [Unemployment rate in Ukraine]. Kyiv: Informatsiino-analitychne ahentstvo. Retrieved from: https://index.minfin.com.ua/ua/labour/unemploy/ (accessed 10 May 2020).

5. Derzhavna sluzhba statystyky Ukrainy (2020). Serednja misjachna zarobitna plata u riznykh krajinakh [Average monthly wages in different countries]. Kyiv: Informatsiino-analitychne ahentstvo. Retrieved from: https://index.minfin.com.ua/ ua/labour/salary/world/ (accessed 10 May 2020).

6. Fostolovych, V. A., \& Shynjkovych A. V. (2010). Suchasna vertykaljno-integhrovana modelj orghanizaciji biznesu iz zamknutym cyklom vyrobnyctva [Modern vertically integrated model of business organization with a closed production cycle]. Ekonomika, finansy. menedzhment: aktualjni pytannja nauky i praktyky, vol. 8, no. 48, pp. 86-103. 